血液濃縮装置 (Hemo - concentrator) の使用経験

\author{
市立旭川病院 胸部外科人工心肺係 \\ 黒田広原田諭伸 \\ 同 胸部外科 \\ 青木秀俊 久保田宏 村上忠司
}

はじめに

近年, 開心術に心筋保護液や局所冷却用乳酸リ ンゲル液を多量に使用するため, 高度な希釈率と なり，ポンプ残血量も増加してきている．乙の希 釈された血液から速やかに除水するために作成さ れた血液濃縮装置（Hemo-concentrator 以下HC と略す）を臨床使用し，体外循環技術からみたと の装置の使用方法, 操作技術を検討し，その臨床 使用経験を報告する。

\section{対象および方法（表 1）}

対象は昭和60年 1 月から 5 月までに当院胸部外 科で行なわれた開心術症例の中から25例を表 1 の 様に, HC を全く使用しなかった群 (control 群, 10例)，HCをポンプ終了近くで使用して血液濃縮 を行い, ポンプ残血を体内にできるだけ返血した 群 ( $\mathrm{HC}-1$ 群, 5 例), $\mathrm{HC}$ を心筋保護液が体内 に入った時点で除水し，体外循環中できるだけ一 定の希釈率にし, 水分管理をした群 ( $\mathrm{HC}-2$ 群, 10例）に分類し, それぞれ, 血液学的検查, 生化

\section{表 1 対象}

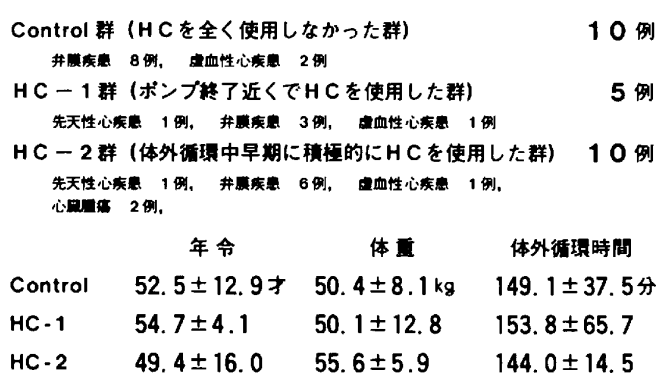

学的検查, 膠質浸透圧, 血将浸透圧, 体外循環中 の尿量および術中出血量, 術後24時間出血量を測 定し, HCの使用方法および操作技術を検討した。

\section{結果}

$\mathrm{Na}, \mathrm{K}, \mathrm{Cl}, \mathrm{BUN}, \mathrm{Cr}$, は 3 群間に体外循環 前，中，終了時にそれぞれ差はなかった。 GOT, GPT, LDHは, 体外循環終了時に, 3 群とも軽 度上昇した。 また, 終了後, 人工肺残血に再度 HC を使用した時のLDHは, 終了時, HC-1群, 641.5
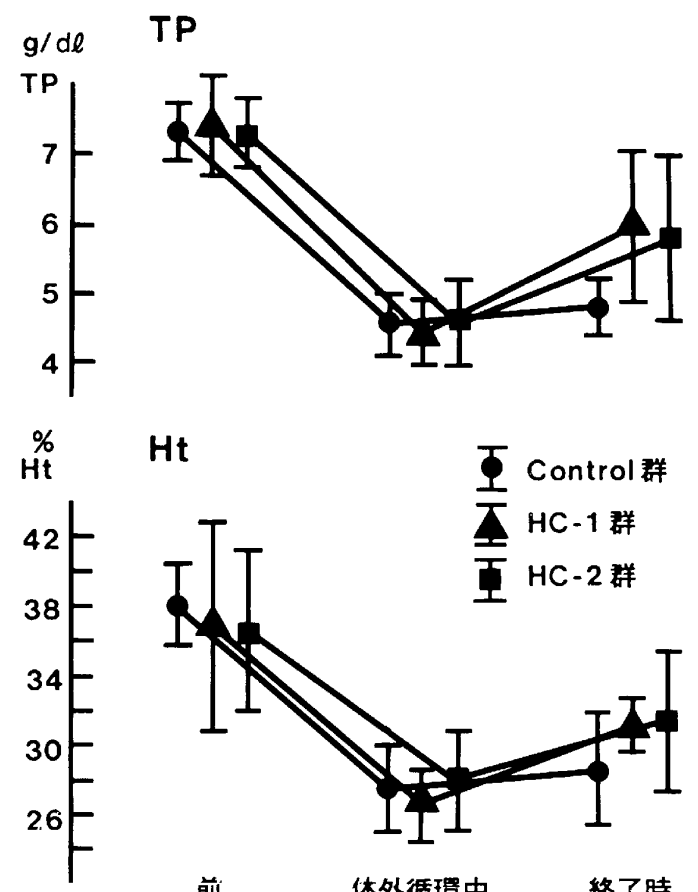

Ht

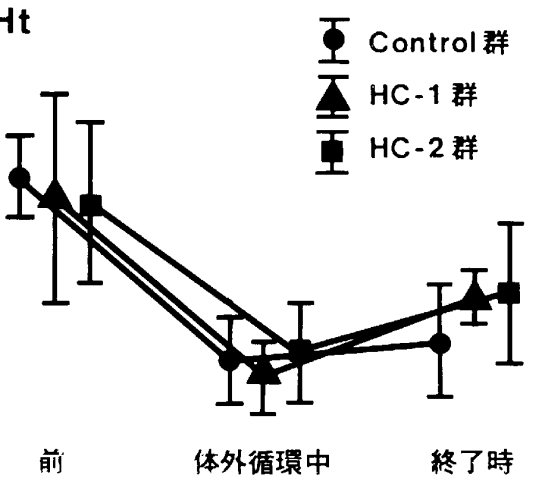

図1 TP及ひ Ht 
$\pm 176.4 \mathrm{u} / \ell$ から $1389.6 \pm 365.4 \mathrm{u} / \ell, \mathrm{HC}-2$ 群, $619.2 \pm 210.9 \mathrm{u} / \ell$ から $1753.0 \pm 863.0 \mathrm{u} / \ell$ と著 しく上昇した。 TP (図 1 ) は, 体外循環中 3 群之 あ低下し，終了時に， HC-1 群, $\mathrm{HC}-2$ 群が con control 群に比べ高かった. Ht (図 1) は, TP と 同じく，体外循環中, 終了時に 3 群とあ低下した が, HC-2群だりは他の群よりあよ゙ちらあ高值で あった。

体外循環中の尿量（図 2) をみると, $\mathrm{HC}-2$ 群 は, Control群に対し有意に少なかった.しかし, 体外循環中に HCで除水した量を含めると, $\mathrm{HC}$ -
2 群はControl群に比べ有意に増加していた。

術中出血量（図 3) は, HC-2 群で Control 群, HC-1 群に対し有意に少なかった。24時間出血量 では，HCを使用した群がControl群に比べ少な かったが有意差はなかった。血䍝浸透压は，3群 間に差はなかった，分時遊離へモグロビン量は Control 群, $0.64 \pm 0.26 \mathrm{mg} / \mathrm{dl} / \mathrm{min}$ であり, $\mathrm{HC}$ -1 群 $0.59 \pm 0.22 \mathrm{mg} / \mathrm{d} \ell / \mathrm{min} ., \mathrm{HC}-2$ 群 $0.58 \pm$ $0.16 \mathrm{mg} / \mathrm{d} l / \mathrm{min}$. であり，体外循環中の分時溶血 量をみるかぎり差はなかった。しかし，終了時の 人工肺残血を再度 $\mathrm{HC}$ を使用した後の遊離へモグ

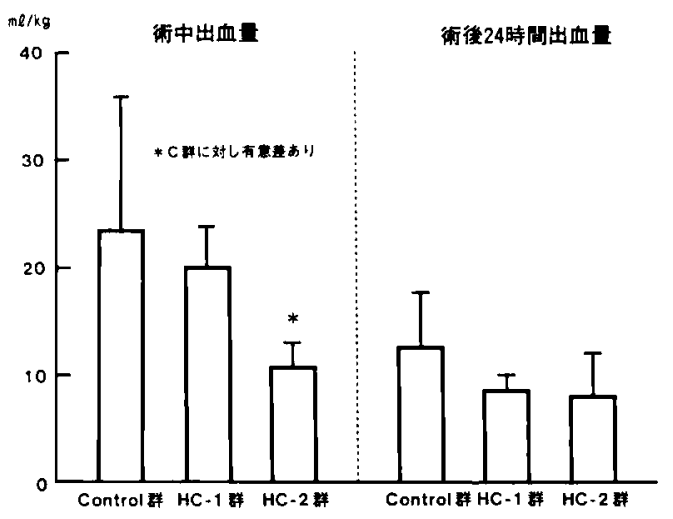

図 3 㭪中出血且及ひ㭪後 24 時間出血量

图 2 体外诸理中の尿量

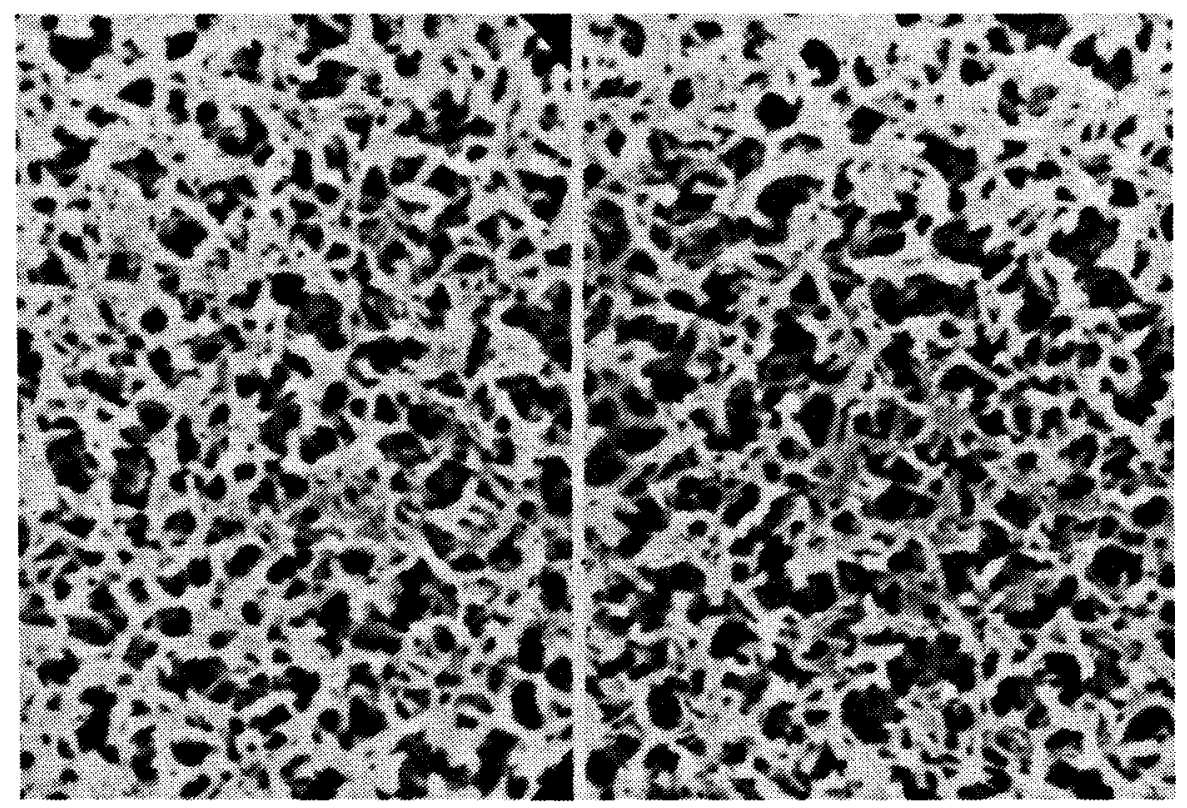

写真 1 減過後の $0.2 \mu$ ナイロンメンブレンフィルターディスクの走查䉓顕像 (左が滤過前, 右が滤過後) 
ロビン量はあきらかに上昇していた。

\section{考察}

$\mathrm{HC}$ は洗浄および充填に大量の生理食塩水を必 要とする. 写真 1 は人工心肺回路洗浄後の生理食 程液を，ポール社製ナイロンメンブレンフィルタ 一ディスク， $0.2 \mu$ で慮過，そのフィルターの走 查電顕像である. 使用前, 後と変化がなかったと とから，人工心肺回路洗浄液を再利用し，HCを洗 浄，充冝している，また，允填の時に気泡をでき るだけ取り除くこ上が望ましいが，直接患者に返 血せず，HC加ら人心肺詝血槽へ厌すため，特に 注意を払わなかったが，除水効果が落ちたことは なかった。

$\mathrm{HC}$ は特別な装置を必要と甘ず，人工心肺装置 のボンブでHCに仙液を送り，限外濾過をして人 以心肺眝血槽に戻方方法を用いている(写真一2). しかし、閉鎖问路システムで体外稙環を行う時に は允分な注意が必要である。

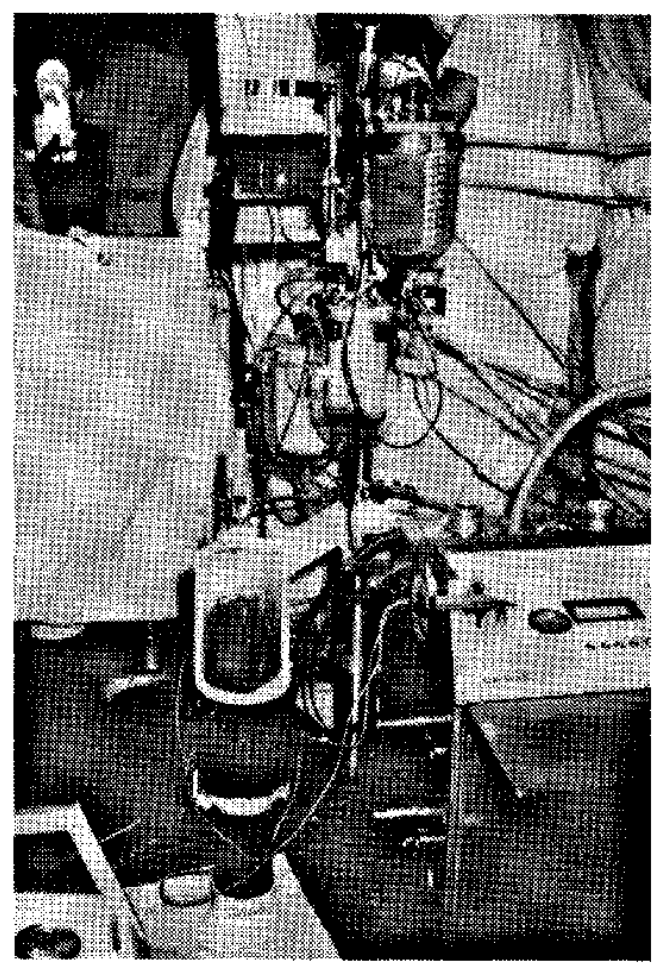

写真 2 体外䛻㻴中の做置

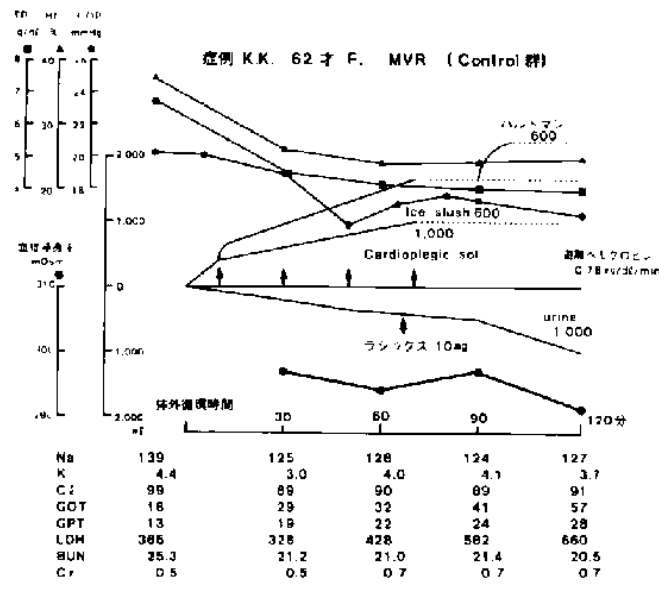

図 4 Contral群の体外循桭中の経過

3 群の体外循環中の経過をそれぞ杖に示す。 Control群（図 4) は，体内红大量の心筋保護液 上Ice slushが入り, Ht, TP, 膠質浸透圧か泜下

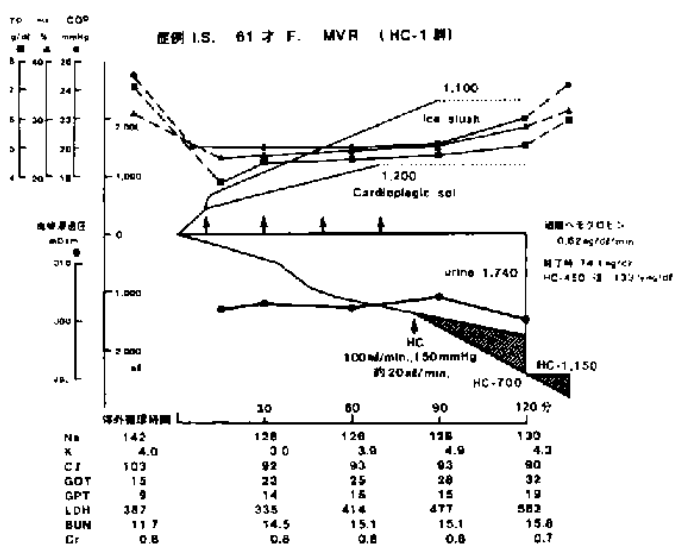

図 $5 \mathrm{HC}-1$ 群の体外猪棵中の経過

したまま体外偱環が終厂している、HC-1群(図 5 ) では, Ht, TP, 膠質浸透圧が, HCでの除水 とともに上昇した。

$\mathrm{HC}-2$ 群 (図 6) では，心筋保護液が多量に人 った時点加ら HCを使用 L， Ht，TP，膠質浸透厈。 を高めに維持して抢り，一定に水分を管理された あの上考えている.

との $\mathrm{HC}$ は, 最高 $80 \mathrm{ml} / \mathrm{min}$. という除水能力 を持方，短時閒で血液濃縮が叮能であり，てれを 返血することにより速やかに体内の $\mathrm{Ht}$ 值を正 常 
にすることができる．また，分子量の大きい蛋白 成分は滤過されず濃縮され，TP や膠質浸透圧を 維持することができる．膠質浸透圧は，毛細血管 と組織間質液間との水分平衡に重要な役割を果し

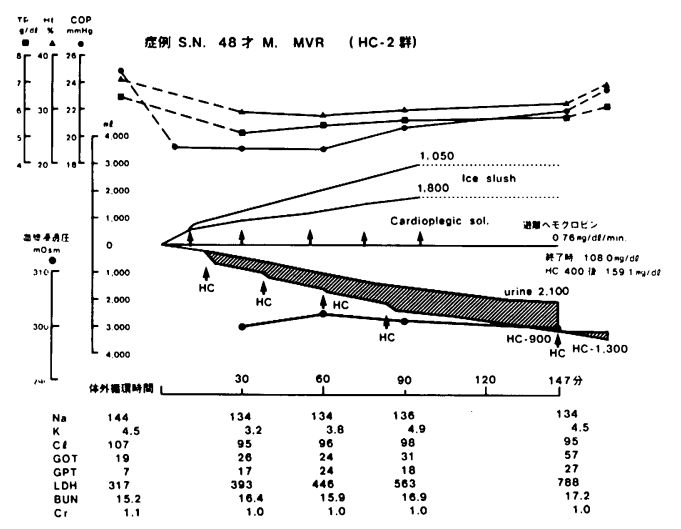

図 $6 \mathrm{HC}-2$ 群の体外循環中の経過

ており，体外循環中の浮腫発生を予防する上で， 膠質浸透圧を維持し，体外循環終了時にはできる だけ高めにするよう努力している，HC-2群では， 術中出血量が, $10.7 \pm 2.4 \mathrm{ml} / \mathrm{kg}$ で, Control群の $22.9 \pm 12.4 \mathrm{ml} / \mathrm{kg}, \mathrm{HC}-1$ 群 $19.5 \pm 4.2 \mathrm{ml} / \mathrm{kg}$ に 対し有意に少なく, 又, 術後24時間出血量む, Control 群 $12.5 \pm 5.0 \mathrm{ml} / \mathrm{kg}, \mathrm{HC}-1$ 群 $8.6 \pm 1.2$ $\mathrm{m} \ell / \mathrm{kg}, \mathrm{HC}-2$ 群 $7.9 \pm 3.9 \mathrm{ml} / \mathrm{kg}$ であり, $\mathrm{HC}$ 使 用群が少ない傾向を示した。 又, 術中の血液使用 量（体外循環中の使用量と体外循環終了後の輸血 量を加えた量）は, Control 群 $2444 \pm 523 \mathrm{ml}$, $\mathrm{HC}-1$ 群 $2340 \pm 900 \mathrm{~m} \ell, \mathrm{HC}-2$ 群 $1480 \pm 500$ $\mathrm{m} \ell$ であり, $\mathrm{HC}-2$ 群が他の群に比べ有意に少な かった. $\mathrm{HC}-2$ 群では, 体外循環中積極的に $\mathrm{HC}$ を使用して除水し, 血液濃縮され, Ht, TP, 膠質 浸透圧が高めに維持されており，血液凝固因子の 温存むなされていると考えられた。また， $\mathrm{HC}-2$ 群はControl群に比べ, 体外循環中尿量が有意に 少なかったが, これは, Control 群で, 積極的に 排尿させるため利尿剂を使用しているからであり しかし, HCにより除水された量を含めると, $\mathrm{HC}$ -2群は Control群より有意に増加していた.てれ は, 体外循環中, 積極的に HC を使用し，水を一 定に管理したあのと考えられる.さらに， HCで
水分を一定に管理するということを考えるならば, 心不全症例のような術前から体内水分量が増加し ている例や，長時間体外循環症例などでは，体外 循環中, 積極的に HCを使用することにより，水 分管理し, 体外循環後の水分負荷からの回復に有 用な使用方法之考えられる. $\mathrm{Na}, \mathrm{K}, \mathrm{Cl}$ や, BUN, $\mathrm{Cr}$ ，などの低分子量のものは，水ととあに濾過さ れる.また，LDHや遊離へモグロビンなどの分子 量の高いものは濾過されずに濃縮された. $\mathrm{HC}-1$ 群での体外循環終了時遊離へモグロビン量は74.1 $\mathrm{mg} / \mathrm{d} \ell$ であったが, 再度 HC 使用後のそれは, $133.9 \mathrm{mg} / \mathrm{d} \ell$ と濃縮された。乙の濃縮された血液 を体内に返血することになるので, 高度溶血例の $\mathrm{HC}$ 使用は充分注意するべきである.

\section{ま と (表 2 )}

体外循環技術からみた $\mathrm{HC}$ 使用方法及び操作技 術を検討した. HC を体外循環終了近くで使用し ながら血液濃縮をし，返血する方法は，技術的に 簡単である．体外循環中に積極的に HC を使用し， 水分を一定に管理する方法は, 体外循環技術とし て重要であり，また操作あ容易である，HC は単 に赤血球濃縮をするのではなく，全血を濃縮する すぐれた装置であり，無血体外循環，長時間体外 循環に有用な装置であると考える。

\section{表2 まとめ}

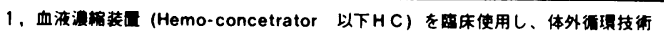
からみた装亚の使用方法及び作技術を掼时した。

2、HCは、特別な装貫を必要とせず、人工心肺装国のボンブと人工心肺回路、而 単な喛引装目で使用できる。

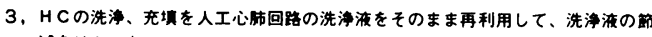
泟をはかった。

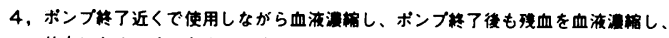

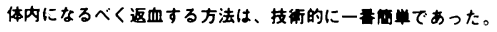

5,HCを心物保源が体内に入った時点から使用し、体外泊理中の水分を一定に

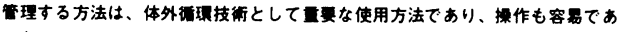
つた。
}

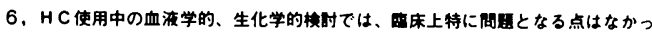

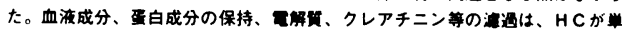

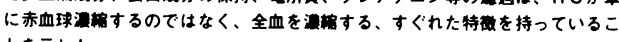
とを示した。

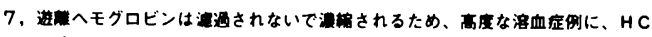
は道していない。

おわりに

血液濃縮装置（Hemo-concent rator）を臨床使 
用し，体外循環技術からみたての装置の使用方法， 操作技術を検討し, その臨床使用経験を報告した。 膠質浸透圧計は, 北海道大学が開発した針型コロ イド浸透圧計，コープスターKA-1000を星盛堂 医療器工業株式会社の御好意により借用し使用し た．ここに厚く感謝致します。また，走査電顕像 は, 旭川医科大学中央実験室, 宮川清氏に依頼し た。ここに深謝致します。

\section{参 考 文 献}

1) 金子俊昌ほか：心臓直視下手術之血䍝渗透圧, 心臓 $10: 377,1978$.

2 ) 杉田洋一：開心術後の血浆膠質浸透圧(COP) の変動に関する臨床的研究, 日胸外会誌 31 : 499, 1983.

3）並木昭義ほか：体外循環時における血浆膠質 浸透圧の変動．麻酔 $32: 836,1983$.

4) 大谷正勝ほか：体外循環におりる限外滤過の 有用性一組織水分量の変化について. 人工臓器 $12(2): 465,1983$.

5 ) 星野俊一ほか : 開心術後の変化, ICU とCCU $8(3): 213,1984$.

6 ）中島進ほか：術後 Anoxia と肺間質浮腫. 呼 吸之循環 $29(10): 1065,1981$.

7 ）北岡建樹ほか：体液浸透圧の測定法. 臨床検
查 $27(12): 1449,1983$.

8 ）武内純夫：無輸血開心術に関する臨床的研究 一とくに体液分布の変動について一. 大阪医大 誌 $41(3) ： 15,1982$.

9 ）吉村博邦：ハローファイバー型人工腎蔵を用 いた体外循環終了後稀釈残液濃縮再利用の研究. 日胸外会誌 $29(7) ： 117 ， 1981$.

10）萩原秀男：人工心肺充填血液の再利用に関す る研究一とくにHaemonetics Cell Saverによ る検討一。日胸外会誌 $28(7): 1047,1980$.

11）仲田勲生ほか：開心術における新しい限外滤 過装置 Hemo-Concent rator ${ }^{\circledR}$ の使用経験. 人工 臓器 $13(1): 512,1984$.

12）仲田勲生ほか：Hemo-Concentrator ${ }^{\circledR}$ を利用 したSingle Pass 限外濾過法による体外循環後 の血液濃縮, 人工藏器 14(3) : 1516, 1985 .

13) Donald J. Magilligan et al : Ultrafiltration During Cardiopulmonary Bypass : Laboratory Evaluation and Initial Clinical Experience. The Annals of Thoracic Suregery. 37(1) 33, 1984.

14) Yehuda Tamari et al : Effects of the Hemo-Concentrator on Blood, The Journal of Extra-Corporeal Technology. 16 (3), 89, 1984. 